\title{
Reduction in the nephrotoxicity of amphotericin B when administered in $20 \%$ intralipid
}

\author{
Suzette Salama B Pharm PhD, Coleman Rotstein BSc MD FRCPC FACP
}

\begin{abstract}
S SALAMA, C ROTSTEIN. Reduction in the nephrotoxicity of amphotericin B when administered in $20 \%$ intralipid. Can J Infect Dis 1997;8(3):157-160. The administration of amphotericin B (AmB) is often limited by the development of nephrotoxicity. In a pilot crossover trial, aqueous AmB followed by a new preparation of a mixture of AmB with $20 \%$ intralipid (AmB-IL) was administered to 10 immunocompromised patients for systemic fungal infections caused by Candida species. Mean total dose and duration of therapy with AmB-IL exceeded that of aqueous $\mathrm{AmB}$ (649 $\pm 165 \mathrm{mg}$ versus $394 \pm 105 \mathrm{mg}, \mathrm{P}=0.061$ and $13.2 \pm 2.5$ days versus $9 \pm 2.1$ days, $\mathrm{P}=0.31$ ). However, mean creatinine clearance of the patients rose during AmB-IL therapy by $10.7 \pm 7.7 \mathrm{~mL} / \mathrm{min}(\mathrm{P}=0.03)$. AmB-IL warrants further investigation to assess its stability and efficacy for treating serious fungal infections.
\end{abstract}

Key Words: Amphotericin B, Candida species, Nephrotoxicity

\section{Réduction de la néphrotoxicité de l'amphotéricine B lors de son administration avec I'intralipide à $20 \%$}

RÉSUMÉ : L'administration d'amphotéricine B est souvent limitée par l'apparition de signes de néphrotoxicité. Dans le cadre d'un essai pilote avec permutation des groupes, de l'amphotéricine B aqueuse (AmB), suivie d'une nouvelle préparation d'amphotéricine $\mathrm{B}$ mélangée à l'intralipide à $20 \%$ (AmB-IL) a été administrée à dix patients immunodéficients pour des infections fongiques à Candida généralisées. La dose moyenne totale et la durée du traitement par AmB-IL ont été supérieures à celles du traitement par AmB aqueux $(649 \pm 165 \mathrm{mg}$ contre $394 \pm 105 \mathrm{mg}, \mathrm{P}=0,061$ et $13,2 \pm 2,5$ jours contre $9 \pm 2,1$ jours, $P=0,31$ ). Toutefois, la clairance moyenne de la créatinine des patients a augmenté de 10,7 $\pm 7,7 \mathrm{~mL} / \mathrm{min}(\mathrm{P}=0,03)$ lors du traitement par AmB-IL. Les résultats enregistrés avec l'AmB-IL justifient la poursuite des recherches pour évaluer sa stabilité et son efficacité dans le traitement des infections fongiques graves.

$\mathrm{F}$ ungal infections have begun to rival those caused by bacteria as significant nosocomial problems (1). Improvement in the prognosis of patients with cancer, immunodeficiencies and connective tissue disorders has created a patient population that more susceptible to infection. The increase in the incidence of nosocomial fungal infection since 1980 has mirrored the expansion of the immunocompromised patient population (2). These infections are often severe, progress rapidly and are refractory to therapy.

Despite the availability and relative success of newer sys-

Departments of Pharmacy and Medicine, The Henderson General Division, Hamilton Civic Hospitals and the Division of Infectious Diseases, McMaster University, Hamilton, Ontario

Correspondence and reprints: Dr Coleman Rotstein, McMaster Medical Unit, Henderson General Hospital, 711 Concession Street Hamilton, Ontario L8V 1C3. Telephone 905-574-3301, fax 905-575-7320, e-mail crotstei@FHS.McMaster.ca

Received for publication March 18, 1996. Accepted November 14, 1996 
TABLE 1

Patient characteristics

\begin{tabular}{|c|c|c|c|c|c|c|c|}
\hline \multirow{2}{*}{$\begin{array}{l}\text { Patient } \\
\text { number }\end{array}$} & \multirow{2}{*}{$\begin{array}{c}\text { Age } \\
\text { (years) }\end{array}$} & \multirow[b]{2}{*}{ Sex } & \multirow[b]{2}{*}{ Diagnosis } & \multirow{2}{*}{$\begin{array}{l}\text { Type of } \\
\text { organism }\end{array}$} & \multirow[b]{2}{*}{ Site of infection } & \multicolumn{2}{|c|}{$\begin{array}{c}\text { Amphotericin B derived } \\
\text { nephrotoxicity }\end{array}$} \\
\hline & & & & & & Aqueous & Lipid \\
\hline 2 & 40 & Female & Acute leukemia & C albicans & Urine & - & - \\
\hline 3 & 59 & Male & Acute leukemia & $\begin{array}{l}\text { Calbicans, } \\
\text { Torulopsis } \\
\text { glabrata }\end{array}$ & Gastrointestinal tract, mouth & - & - \\
\hline 4 & 67 & Female & Acute leukemia & Candida tropicalis & Blood & - & - \\
\hline 5 & 53 & Female & Lymphoma & C albicans & Blood, urine, lungs & + & - \\
\hline 6 & 57 & Male & Acute leukemia & $\begin{array}{l}\text { Calbicans, } \\
\text { Candida lambica }\end{array}$ & Gastrointestinal tract & + & - \\
\hline 7 & 32 & Female & Lymphoma & $\begin{array}{l}\text { Candida } \\
\text { lusitaniae }\end{array}$ & Vagina & + & - \\
\hline 9 & 60 & Female & Acute leukemia & C albicans & $\begin{array}{l}\text { Urine, mouth, gastrointestinal } \\
\text { tract }\end{array}$ & + & - \\
\hline 10 & 36 & Male & Crohn's disease & C albicans & Blood & - & - \\
\hline
\end{tabular}

- Nephrotoxicity absent; + Nephrotoxicity present

temic antifungal agents such as fluconazole (3) and itraconazole (4), amphotericin B (AmB) has remained the treatment of choice for systemic fungal infections. However, the clinical use of AmB is complicated by the development of a variety of adverse events including fever, chills, nausea, vomiting, hypokalemia, hypomagnesemia and anemia (5). The most formidable of these effects, nephrotoxicity, may actually restrict AmB's effectiveness because of premature discontinuation of antifungal therapy or suboptimal dosing (6).

One approach to circumventing nephrotoxicity has been the formulation of preparations of AmB that are less toxic (7). As a result, $A m B$ has been entrapped in liposomes, ambisome or amphotericin B lipid complex (ABLC), and complexed with cholesteryl sulfate, amphotericin B colloidal dispersion $(\mathrm{ABCD})$. Ambisome is a liposomal preparation of small unilaminar vesicles with a particle size $80 \mathrm{~nm}$, containing a $10 \%$ concentration of $\mathrm{AmB}$ in the membrane (8). $\mathrm{ABLC}$ is an $\mathrm{AmB}$ lipid complex with a particle size of 1.6 to $11 \mu \mathrm{m}$ that includes an approximately $33 \%$ concentration of AmB in microparticulate polymorphic sheets and ribbons (8). Finally, $A B C D$ is a stable complex of $\mathrm{AmB}$ and cholesteryl sulfate intercalated in a 1:1 ratio in disc-like structures with a diameter of $122 \mathrm{mn}$ (8). All three formulations have been administered at higher dosages, 5 to $7 \mathrm{mg} / \mathrm{kg} / \mathrm{day}$, than AmB (9). These preparations have proven to be efficacious with reduced renal toxicity for the treatment of fungal infections in immunocompromised hosts (10-12). Nevertheless, the formulations are very expensive. An alternative, less expensive delivery system has been studied by Anaissie et al (11), Chavanet et al (13) and Caillot et al (14). This lipid emulsion mixture with AmB was demonstrated to reduce toxicity while maintaining efficacy
$(11,13,14)$. We, therefore, decided to conduct our own pilot study to assess the effect of $\mathrm{AmB}$ mixed with $20 \%$ intralipid on the renal function of immunocompromised patients.

\section{PATIENTS AND METHODS}

Ten immunocompromised patients (eight with an underlying hematological malignancy, one with diabetes mellitus and rheumatoid arthritis, and one with Crohn's disease) with a systemic fungal infection due to a Candida species were initially given AmB in aqueous solution. The presence of a systemic fungal infection was determined by the patient's attending physician based on microbiological documentation of Candida species from a body site in the clinical setting of fever, presumed to be infectious in etiology.

Aqueous AmB was given at a dose of $0.6 \mathrm{mg} / \mathrm{kg} /$ day intravenously after an initial test dose of $1 \mathrm{mg}$ in $100 \mathrm{~mL}$ of dextrose and water solution infused intravenously over $1 \mathrm{~h}$. AmB was reconstituted in $10 \mathrm{~mL}$ of dextrose and water solution and subsequently diluted in $500 \mathrm{~mL}$ of the same intravenous solution. The aqueous AmB solution was then infused intravenously daily over $4 \mathrm{~h}$. Premedication with acetaminophen $650 \mathrm{mg}$ orally, intravenous diphenhydramine 25 or 50 $\mathrm{mg}$ and intravenous meperidine 25 or $50 \mathrm{mg}$ was given to each patient.

Each patient was crossed over from aqueous $\mathrm{AmB}$ to $\mathrm{AmB}$ in $20 \%$ intralipid (AmB-IL). This occurred during the treatment course in six cases and at the onset of nephrotoxicity in four patients. The same premedication was employed. Nephrotoxicity was defined as a $50 \%$ decrease from the baseline value in calculated creatinine clearance (15).

AmB-IL was prepared daily in the following manner. Based 
TABLE 2

Comparison of aqueous amphotericin B and amphotericin B in intralipid for dosage and renal function

\begin{tabular}{cccc}
\hline & $\begin{array}{c}\text { Mean total } \\
\text { dose } \\
(\mathbf{m g} \pm \mathbf{S D})\end{array}$ & $\begin{array}{c}\text { Mean } \\
\text { treatment } \\
\text { duration } \\
(\mathbf{d a y s} \pm \mathbf{S D})\end{array}$ & $\begin{array}{c}\text { Mean change } \\
\text { in creatinine } \\
\text { clearance } \\
(\mathbf{m L} / \mathbf{m i n} \pm \mathbf{S D})\end{array}$ \\
\hline Amphotericin B & $344 \pm 105$ & $9 \pm 2.1$ & $-23.5 \pm 9.2$ \\
$\begin{array}{c}\text { Amphotericin B } \\
\text { in intralipid }\end{array}$ & $649 \pm 165$ & $13.2 \pm 2.5$ & $+10.7 \pm 7.7$ \\
$\mathrm{P}$ & 0.064 & 0.307 & 0.026 \\
\hline
\end{tabular}

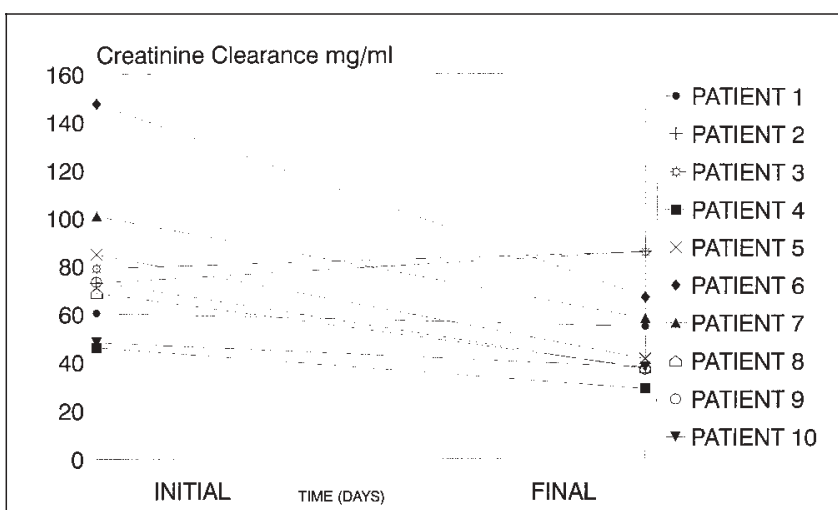

Figure 1) Baseline and ending creatinine clearance values for patients treated with aqueous amphotercin B. Creatinine clearance was calculated using the Cockcroft and Gault formula

on a dosage of $1 \mathrm{mg} / \mathrm{kg} /$ day, the daily requirement of $\mathrm{AmB}$ to be administered was calculated. AmB (50 mg/vial) was then reconstituted in $10 \mathrm{~mL}$ of sterile water for injection to yield a final concentration of $5 \mathrm{mg} / \mathrm{mL}$. The required daily dosage of AmB was then transferred from the reconstituted preparation of $5 \mathrm{mg} / \mathrm{mL}$ to a $100 \mathrm{~mL}$ bottle of $20 \%$ intralipid (Kabi Pharmacia Canada Inc) fat emulsion for parenteral use. This was mixed and shaken thoroughly for 2 mins. The mixture was protected from light and refrigerated. The AmB-IL formulation was infused intravenously over $2 \mathrm{~h}$ within $24 \mathrm{~h}$ of its preparation. No premedication was administered.

Patient characteristics were recorded including age; sex; underlying diagnosis; site of infection; organism type; baseline and end of therapy serum creatinines, potassium, magnesium, asparate aminotransferase, alanine aminotransferase, gamma-glutamyl transpeptidase, alkaline phosphatase and bilirubin; duration of therapy with aqueous AmB and AmB-IL. The total dose administered of each formulation was also recorded. Mean total dose of each formulation of AmB, mean duration of treatment and mean change in calculated creatinine clearance based on initial and end of therapy values for each formulation of $\mathrm{AmB}$, respectively, were compared by paired Student's $t$ tests.

\section{RESULTS}

Ten immunocompromised patients were initially treated with aqueous AmB and were then crossed over to AmB-IL. Table 1 details the characteristics of the patients. Six patients

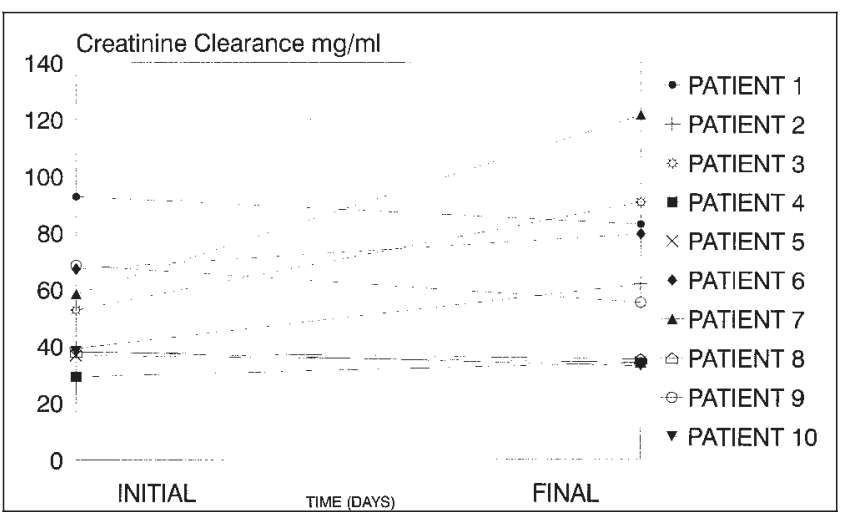

Figure 2) Baseline and ending creatinine clearance values for patients treated with amphotercin $B$ in intralipid. Creatinine clearance was calculated using the Cockcroft and Gault formula

TABLE 3

Mean changes in serum electrolytes and liver enzymes

\begin{tabular}{lccc}
\hline $\begin{array}{l}\text { Biochemical } \\
\text { parameter }\end{array}$ & $\begin{array}{c}\text { Aqueous } \\
\text { amphotericin B }\end{array}$ & $\begin{array}{c}\text { Amphotericin } \\
\text { B in }\end{array}$ & \\
\hline $\begin{array}{l}\text { Serum potassium } \\
(\mathrm{mmol} / \mathrm{L})\end{array}$ & $0.14 \pm 0.3$ & $0.4 \pm 1.2$ & 0.95 \\
$\begin{array}{l}\text { Serum magnesium } \\
(\mathrm{mmol} / \mathrm{L})\end{array}$ & $0.036 \pm 0.1$ & $0.009 \pm 0.12$ & 0.93 \\
$\begin{array}{l}\text { Asparate amino- } \\
\text { transferase }(\mathrm{U} / \mathrm{L})\end{array}$ & $-2.0 \pm 5.1$ & $10.4 \pm 17.6$ & 0.97 \\
$\begin{array}{c}\text { Alanine transferase } \\
(\mathrm{U} / \mathrm{L})\end{array}$ & $7.9 \pm 22.7$ & $15.2 \pm 31.7$ & 1.03 \\
$\begin{array}{c}\text { Gamma-glutamyl } \\
\text { transpeptidase }(\mathrm{U} / \mathrm{L})\end{array}$ & $-2.3 \pm 56.3$ & $49.3 \pm 123.8$ & 1.15 \\
$\begin{array}{c}\text { Alkaline phosphate } \\
(\mathrm{U} / \mathrm{L})\end{array}$ & $21.2 \pm 28.3$ & $11.4 \pm 44.8$ & 1.04 \\
$\begin{array}{c}\text { Total bilirubin } \\
(\mu \mathrm{mol} / \mathrm{L})\end{array}$ & $6.1 \pm 10.3$ & $3.3 \pm 23.3$ & 0.59 \\
\hline
\end{tabular}

with underlying acute leukemia and two patients with lymphoma had recently completed antineoplastic chemotherapy. One patient, with a history of diabetes mellitus, rheumatoid arthritis and renal insufficiency, developed candiduria and candidemia. Another patient developed a central venous access device-related candidemia while receiving total parenteral nutrition for Crohn's disease. There were six female and four male patients, mean age 52 years. Causative pathogens were Candida albicans in six patients, Candida tropicalis in one, Candida lusitaniae in one, $C$ albicans with Torulopsis glabrata in one, and $C$ albicans with Candida lambica in one. Sources of infection were urine, bloodstream and gastrointestinal tract (neutropenic enteropathy).

The mean total dose of AmB-IL exceeded that of aqueous AmB (649 $\pm 165 \mathrm{mg}$ versus $344 \pm 105 \mathrm{mg}, \mathrm{P}=0.06)$, as did the mean duration of treatment (13.2 \pm 2.5 versus $9 \pm 2.1$ days; $\mathrm{P}=0.31$ ) (Table 2). However, during the aqueous AmB treatment, the mean creatinine clearance for the group dropped by $23.5 \pm 9.2 \mathrm{~mL} / \mathrm{min}$ (Figure 1). Thereafter, during AmB-IL therapy, the mean creatinine clearance rose by $10.7 \pm 7.7 \mathrm{~mL} / \mathrm{min}$ 
$(P=0.03)$ (Figure 2). Nevertheless, in contrast with the improvement in creatinine clearance observed with AmB-IL, it had no significant beneficial effect on other biochemical laboratory parameters commonly affected by AmB (Table 3).

\section{DISCUSSION}

Our crossover study clearly demonstrated that AmB-IL was less nephrotoxic than aqueous AmB. Even though our immunocompromised patient sample received a higher concentration of AmB-IL than aqueous AmB (1 $\mathrm{mg} / \mathrm{kg} /$ day versus $0.6 \mathrm{mg} / \mathrm{kg} /$ day), a larger mean total dose and a longer length of therapy, mean creatinine clearance rose significantly during the AmB-IL phase of treatment. Although it is unclear whether AmB nephrotoxicity is dose-dependent (6), our findings clearly delineate the improvement in creatinine clearance associated with AmB-IL administration, even with administration of more of the latter preparation. Some investigators have demonstrated a renal sparing effect with AmB-IL compared with aqueous AmB (10); nevertheless, others have still noted significant reductions in creatinine clearance with a fat emulsion preparation (11). This latter finding may have been related to the addition of flucytosine (11).

However, there are a number of limitations to our observations. First, because aqueous AmB was initiated when sepsis was recognized, other factors such as concomitant hypoten-

\section{REFERENCES}

1. Bodey GP. The emergence of fungi as major hospital pathogens. J Hosp Infect 1988;11:411-26.

2. Beck-Sague CM, Jarvis WR, The National Nosocomial Infections Surveillance System. Secular trends in the epidemiology of nosocomial fungal infections in the United States 1980-1990. J Infect Dis 1993; 167:1247-51.

3. Rex JH, Bennett JE, Sugar AM, et al. A randomized trial comparing fluconazole with amphotericin B for the treatment of candidemia in patients without neutropenia. $\mathrm{N}$ Engl J Med 1994;331:1325-30.

4. Zuckerman JM, Tunkel AR. Itraconazole: A new triazole antifungal agent. Infect Control Hosp Epidemiol 1994;15:397-410.

5. Gallis H, Drew R, Pickard W. Amphotericin B: 30 years of clinical experience. Rev Infect Dis 1990;12:308-28.

6. Branch RA. Prevention of amphotericin B-induced renal impairment: A review on the use of sodium supplementation. Arch Intern Med 1988;148:2389-94.

7. Schmitt HJ. New methods of delivery of amphotericin B. Clin Infect Dis 1993;17(Suppl 2):S501-6.

8. Janknegt R, de Marie S, Bakker-Woudenberg AJM, Crommelin DJA. Liposomal and lipid formulations of amphotericin B: Clinical pharmacokinetics. Clin Pharmacokinet 1992;23:279-91.

9. Graybill JR. The future of antifungal therapy. Clin Infect Dis 1996;22(Suppl 2):S166-78. sion or other nephrotoxins may have contributed to the nephrotoxicity observed. Second, we could not assess the efficacy of the AmB-IL preparation. This is relevant because it has been speculated that AmB-IL produces less toxicity by trapping and binding AmB molecules in the lipid portion, thus reducing the availability of free and active AmB compound (7). Similarly, serum concentrations of free AmB in the AmB-IL mixture are lower than aqueous $\mathrm{AmB}$ (10). It may be necessary to infuse higher doses of AmB-IL to attain the efficacy rates achieved by aqueous AmB $(7,10)$. Third, we did not demonstrate the permanent stability and absolute safety of our mixture. Concerns have been raised that AmB-IL may contain particles at least 10 $\mu \mathrm{m}$ in diameter (16) and that these particles may lodge in blood vessels. Aqueous AmB consistently had particles of less than $10 \mu \mathrm{m}$. Finally, it would have been advantageous for all our patients to cross over from aqueous AmB to AmB-IL at a specified AmB dose.

In this crossover pilot study where patients acted as their own controls, AmB-induced nephrotoxicity was significantly reduced with AmB-IL. This mixture warrants further evaluation of its long term stability, safety, clinical efficacy and maximum tolerated dose. Because the costs of AmB-IL are substantially less than ABLC, $A B C D$ or liposomal AmB, the mixture may prove to be a welcome addition to our antifungal armamentarium.

10. Ringden 0, Meunier F, Tollemar J, et al. Effect of amphotericin B encapsulated in liposomes (ambisome) in the treatment of invasive fungal infections in immunocompromised patients. J Antimicrob Chemother 1991;28(Suppl B):73-82.

11. Anaissie EJ, White M, Uzon O, et al. Amphotericin B lipid complex (ABLC) versus amphotericin B (AMB) for the treatment of hematogenous invasive candidiasis: A prospective randomized multicenter trial. Thirty-fifth Interscience Conference on Antimicrobial Agents and Chemotherapy. San Francisco, September, 17-20, 1995. (Abst)

12. Oppenheim BA, Herbrecht R, Kusne S. The safety and efficacy of amphotericin B colloidal dispersion in the treatment of invasive mycoses. Clin Infect Dis 1995;21:1145-53.

13. Chavanet PY, Garry I, Charlier N, et al. Trial of glucose versus fat emulsion in preparation of amphotericin B for use in HIV infected patients with candidiasis. BM] 1992;305:921-5.

14. Caillot D, Casasnovas O, Solary E, et al. Efficacy and tolerance of an amphotericin B lipid (intralipid) emulsion in the treatment of candidaemia in neutropenic patients. J Antimicrob Chemother 1993;31:161-9.

15. Cockcroft DW, Gault MH. Prediction of creatinine clearance from serum creatinine. Nephron 1976;16:31-41.

16. Trissel LA. Amphotericin B does not mix with fat emulsion. Am J Health-Sys Pharm 1995;52:1463-4. 


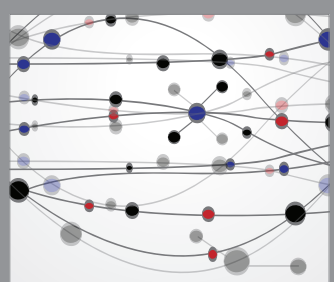

The Scientific World Journal
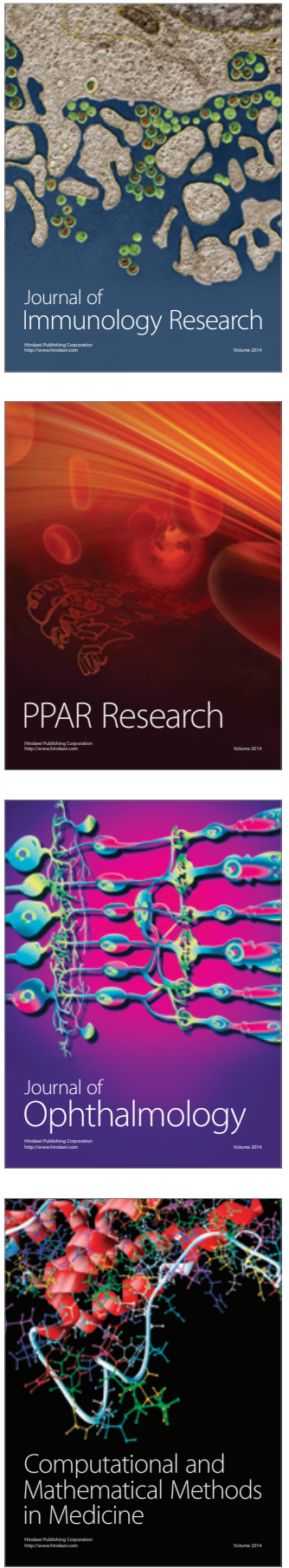

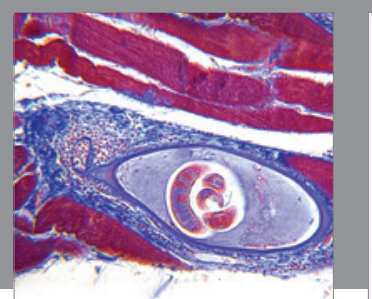

Gastroenterology Research and Practice

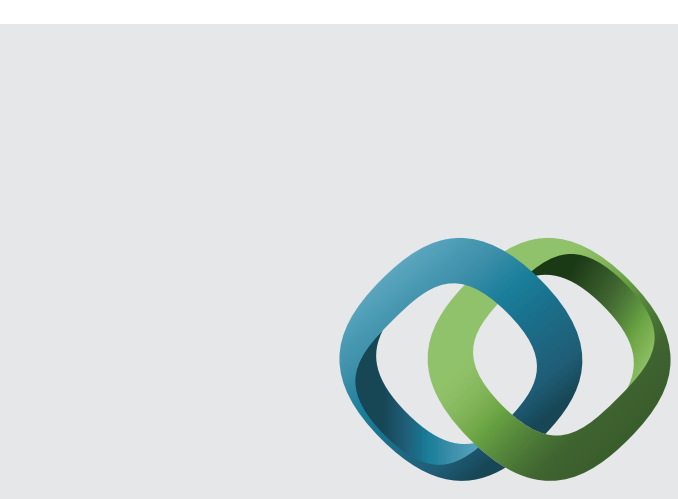

\section{Hindawi}

Submit your manuscripts at

http://www.hindawi.com
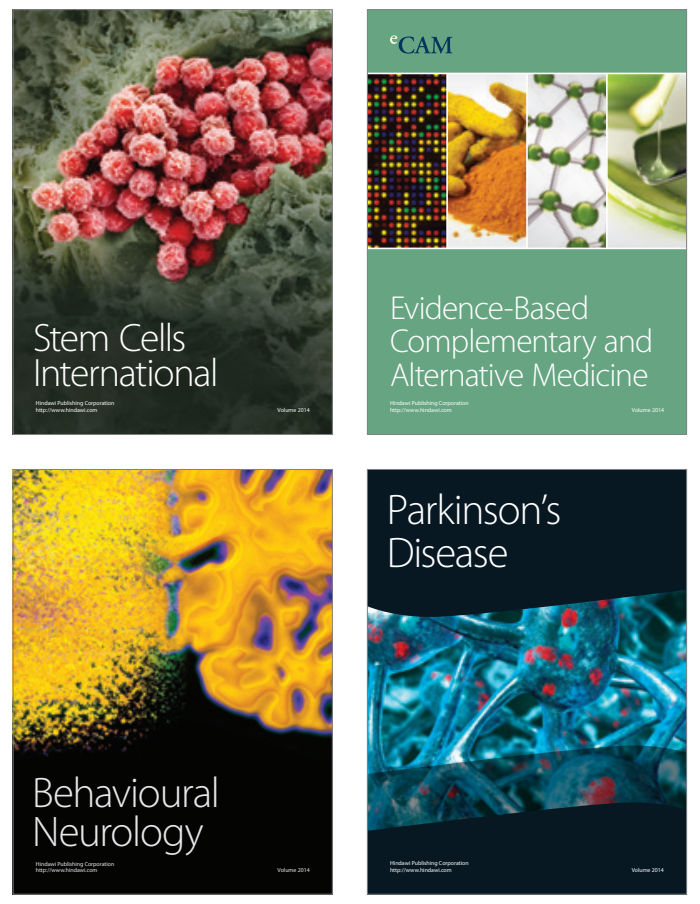
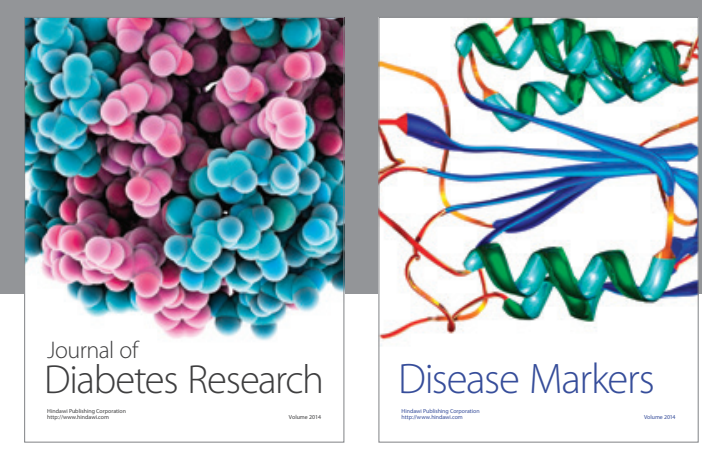

Disease Markers
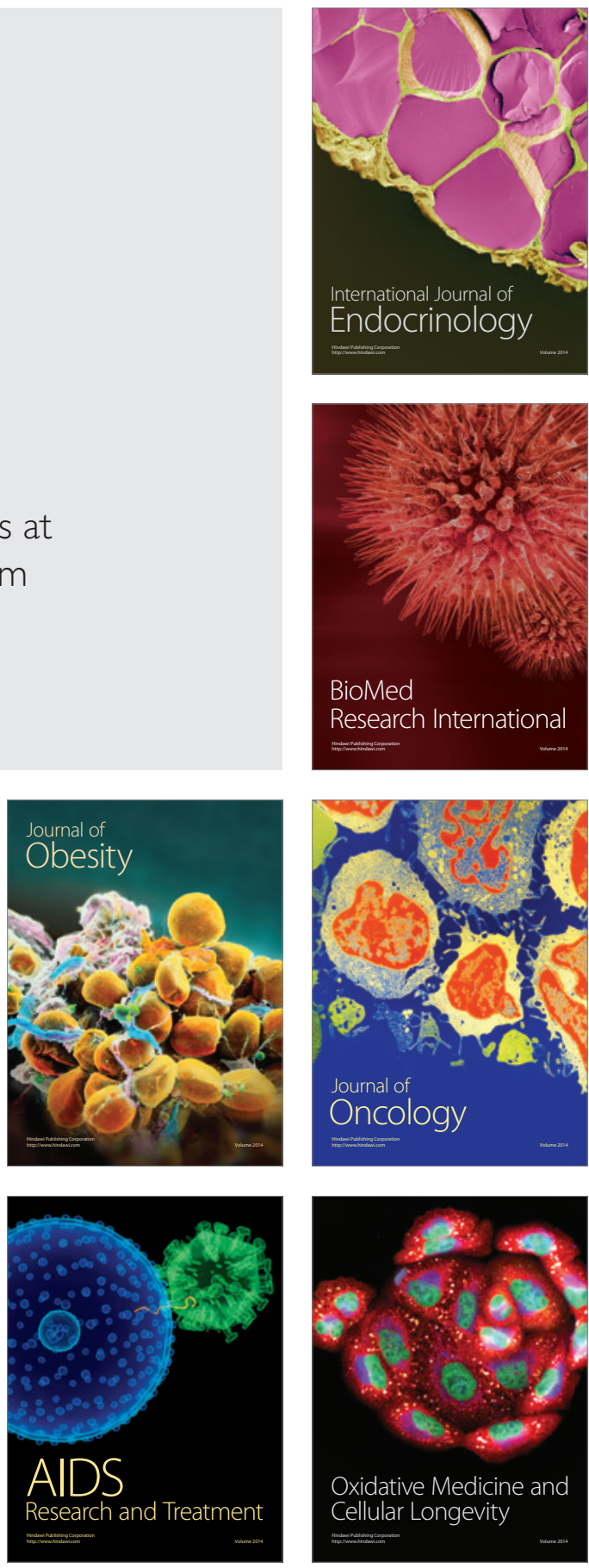